\title{
The Decline of a Power in Khurāsān and Transoxiana in the Period of Umaiyad Caliphate
}

\author{
HASAN KURT \\ DOÇ. DR, ANK ARA Ü. İLAHI YAT FAKÜLTESI \\ e-mail: kurt@divinity.ankara.edu.tr
}

özet

Emeviler Döneminde Horasan ve Maveraünnehirde Bir Iktidann Çöküşü. Bu makale Emevîler döneminde devlet içinde çok nüfuzlu bir konumda bulunan Haccac b. Yusuf'a bağl olarak Horasan ve Maveraünnehir'de valilik yapan Kuteybe b. Müslim'in görevde kalma mücadelesini ve hazin sonunu konu etmektedir. Böylelikle söz konusu dönemde bu bölgenin içinde bulunduğu siyasî durumu aydınlüga kavuşturmaya çalı̨̧makıadır.

anahtar kelimeler

Kuteybe b. Müslim, Maveraünnehir, Horasan, Haccac b. Yusuf, Süleyman b. Abdülmelik

\section{Introduction}

In the period of Umaiyad Caliphate, Khurāsān had a much wider region, everywhere east of westem of Persia, strecthing from Gurgān and Kümis in the southeastern Caspian region to Badakhshān and Tukhāristan on the upper Oxus and Bāmiyān in the Hindū Kush. As for Transoxiana, it bordered Khurāsān and Khwārazm in west and Badakhshān in south along parts of the Oxus. 1

The Arabs conquered Khurāsān to Oxus in 22/642-643 in the period of the Caliph 'Umar b. al-Khattāb' and attempted to conquer Transoxiana in the years after 51/671, in the period of Umaiyad Caliphate. Khurāsān and Transoxiana were generally ruled by a govemer who had been appointed by the Viceroy of 'Iraq. The Arabs, as rulers, failed to control over Khurāsān and especially Transoxiana until the appointment of Qutaiba b. Muslim there as governer by the Viceroy of 'Irāq and Khurāsān Hajjāj b. Yūsuf in the

1 Yãqūt al-Óamaw̄i, Mưcam al-Buldān, (Beirut 1979), V, 45; Abū al-Fidā, Tą̣wìm al-Buldān, ed.M.Reinaud, M. Le Baron Mac Guckin de Slane, (Pans 1840), 483.

2 al-Tabañ, Tãnikh al-Rusul wa'l-Mulūk, ed. Mohammad Abūl Faêl Ibrāhīm, (Cairo n.d.), IV, 171; Ibn Kathīr, al-Bidāya wa al-Nihāya, (Cairo n.d.), VII, 139-140. 
period of Umaiyad Caliph Walid b. 'Abd al-Malik. Because the Arab tribes quarrelled with each other as from Yazīd b. Mu'āwiya became caliph. Basran troops, and especially the men of the North Arab or Kaisi tribes of Tamim and Bakr, among the Arab tribes were prominent in the overnunning of Khurāsān and Transoxiana, though in the governorship of al-Muhallab b. Abi Sufra (78-82/697-702), considerable numbers of that governer's fellowtribesmen of the Yamani Azd were settled there. ${ }^{3}$

As from the period of the Umaiyad Caliph 'Abd al-Malik b. Marwān to the period of Caliph Sulaiman b. 'Abd al-Malik, Óajjāj had the power to appoint governors in more than half of the empire, and started a certain school of governors, which outlived him by many years, and which was rightly called the Óajjäj school and its members were named the sreords of Óajjaj. ${ }^{4}$

In the period of the Caliph Walid, Óajjäj attained peak of his power and much influenced on him. Thus even Governor of the Óijāz 'Umar b. 'Abd al-'Azīz, who would be appointed as caliph after Sulaiman b. 'Abd al-Malik, was overcome by Óajjāj. 'Umar b. 'Abd al-'Aziz had been in correspondence with the Caliph Walid that Óajjāj had tyrannized over the 'Irāqians, of which Óajjāj had been informed. Thereupon Óajjaj informed the Caliph Walid about the fact that the bandits of 'Irāq took shelter in the Óijāz whose governor was 'Umar. Consequently the Caliph Walid supported Óajjāj against 'Umar who was from Umaiyad dynasty, and dismissed him in Sha'bān 93/May 712 from governorship of the Óijāz. By the advice of Óajjāj, the Caliph Walìd divided governorship of Óijāz into two parts, Mecca and Medina; and appointed Khālid b. 'Abdallāh to Mecca, and 'Uthmān b. Óaiyān to Medina as governors. 5

Óajjāj took much precaution against possible threats to cause harm his influence on the bureaucracy of the Umaiyads. Even he intervened the appointment of heirship apparent. In this way he tried to have an influence on the next caliph. As an instance of this, Óajjäj attempted on the dismissal of Sulaiman b. 'Abd al-Malik from heirship apparent, who was brother of the Caliph Walid, and the appointment of 'Abd al-'Aziz who was son of the Caliph Walid as heir apparent instead, and tried to satisfy the ministers and high officials in this respect. 6 But neither Óajjäj's life nor Caliph Walid's

\footnotetext{
${ }^{3}$ See more information Hasan Kurt, Orta Asya'nun Islâmlașma Süreci (Buhârâ Örneği), (Ankara 1998), 143-159.

4 al-Ũabari, VI, 559; Shaban, The Abbāsid Revolution, (Cambridge 1972), 72.

5 al-Ùabañ, VI, 481-482.

6 al-Balādhurī, Fuñ̄h al-Buldān, trans. Mustafa Fayda, (Ankara 1987), 615; al-Ùabarī, VI, 498-9.
} 
were enough to dismiss Sulaiman b. 'Abd al-Malik from heirship apparent. In that term Qutaiba b. Muslim ruled Khurāsān and Transoxiana as governer of Hajjāj. He ended quarrel among the 'Arab tribes in Khurāsān, and urged them to conquer the lands of Transoxiana. So 'Arab tribes under Qutaiba conquered many lands of Transoxiana including Tokhāristān, Bukhārā, Ùāliqān, Shūmān, Kish, Nasaf, Khwārazm, Samarqand, Shāsh, Ferghāna, Kashgar.

This success for Qutaiba was by virtue of Óajjāj. Therefore he was one of the most loyal men to the school of Óajjäj and was more faithful to him than to the Umaiyad Caliph Walid b. 'Abd al-Malik. When Óajjāj died in 95/714, Qutaiba suspected that he would be dismissed from the governorship of Khurāañn and stopped the campaign of Shāsh and come back to Merv, the centre of 'Arab military operations in Khurāsān. But the Caliph Walid wanted him to remain in governorship duty.8 Moreover the tribe of Qutaiba, Bāhila, and the tribe of Óajjāj, Thaqiph, were relatives and branchs of Qais tribe. But since Qutaiba wasn't the leader of his tribe, he had hardly any influence over them. In addition, his tribe Bāhila was more powerless to the other tribes. There was also no any special army under him except the soldiers of tribes. 9 As a result of that loyalty to Hajjäj, Qutaiba at most had supported in his attempts on the dismissal of Sulaiman from heirship apparent. However, in the end, Sulaiman was able to become caliph, and a new period began in the Umaiyad Caliphate. But at the beginning of this period, bloody struggles happened in Khurāsān and Transoxiana, and the Óajjaj school declined in this region.

\section{Qutaiba b. Muslim's Struggle to Remain in Khurāsān as Governor}

The appointment of Sulaiman b. 'Abd al-Malik to the caliphate was the beginning of the end in governorship for Qutaiba. As an important member of Hajjàj school, Qutaiba reacted to this appointing and compared the Caliph Sulaiman to Yazīd b. Sarwān who was famous with his stupidity, and said that Habarmaqat al-'Aisbi, or the stupid member of 'Áisha, became your caliph. Úabarī and Ibn A'tham al-Kūfī narrated this nickname as Habarmaqat al-Qaisi, or a stupid person from the Qais tribe. It was said that Yazid b. Sarwān fed only fleshy camels, not lean ones, and told that he couldn't heal

\footnotetext{
7 See al-Ùabañ, VI, 428-433, 436-437, 439-440, 442-447, 454-464, 469-481, 483-485, 500-504.

8 al-Üabari, VI, 492.

9 al-Ùabarī, VI, 424.
} 
ones God healed. Likewise Qutaiba asserted that Sulaiman b. 'Abd al-Malik donated to the wealthy, not the poor. ${ }^{10}$

Although Qutaiba thought that he would be dismissed from his office, he tried not to panic at the beginning of caliphate of Sulaiman. According to 'Alì b. Muóammad al-Madāinī, Qutaiba wrote the Caliph Sulaiman three letters and gave them an envoy, who was from his tribe, to take away the Caliph. In the first letter, Qutaiba was congratulating him on his being appointed as caliph. In the second one, he was writing about the lands which he conquered, and his victory in the wars, and his consideration among the native kings in Khurāsān and Transoxiana, and how they avoid him. In addition, he criticized Yazid b. al-Muhallab whose governorship after him was possible. Because Qutaiba had been appointed to the govemorship instead of al-Muhallabids by Óajjāj, Viceroy of 'Irāq and Khurāsān. He thought that Yazid b. al-Muhallab, whose relation with the Caliph Sulaiman was very sincerely, would be appointed as governor of Khurāsān instead of himself. In the third one, Qutaiba was determining that he didn't recognize the Caliph Sulaiman as caliph. Considering that Yazid would be before the Caliph, Qutaiba said to his envoy: "Give the first letter to the Caliph. If he reads it and shows it to Yazid, give the second one. If he makes it clear to Yazid, give the third one to the Caliph, but if not, do not." Abū "Ubaida Ma'mar b. Muthannā differently narrated the contents of letters. According to him, Qutaiba wrote about his achievements, and critisized Yazid in the first letter. In the second one, he praised Yazid. In the third one, he threatened the Caliph Sulaiman, expressed his determination not to recognize his caliphate, and stated his intention to fight against him. ${ }^{11}$

When compared to the narrative of Abū 'Ubaida, the narrative of alMadāinī seems relatively more realistic. Because it was more reasonable that Qutaiba was firstly in praise of the new Caliph, and he secondly mentioned their successful activities and his consideration among the native kings in Khurāsān and Transoxiana. However, it doesn't matter whether the narrative of al-Madāinī was true or Abū 'Ubaida's; both of them referred Qutaiba wanted the new Caliph Sulaiman to let him to remain in his office. In

\footnotetext{
10 al-Balādhurī, 615; al-Ùabarī, VI, 509; Ibn A'tham al-Kūfī, Kitāb al-Funūh, (Beirut 1987), IV, 194.

11 al-Üabari, VI, 506-508. Acconding to Ibn A'tham al-Küfí, after the appointment of Yazid b. alMuhallab as the govemor of Khurāsān, Qutaiba b. Muslim firstly sent a letter to the Caliph Sulaiman b. Abd al-Malik congratulating him on his appointment as caliph and afterwards the three letters in question. See Ibn A'tham al-Kuffi, IV, 187-192. Whereas, according to the other sources, Yazid b. alMuhallab was firstly appointed as the govemor of 'Irāq, secondly as the govemor of Khurāsān about a year later.
} 
addition, it was not uncommon that Qutaiba competed with Yazid for the governorship of Khurāsān. Because Yazīd had governed Khurāsān and Transoxiana before Qutaiba did, and had been dismissed from governership and had been blamed to have embezzled and had been fined 6.000.000 dirham and had wanted Sulaiman, the heir apparent of the Caliph Walid, to protect for himself. Sulaiman b. 'Abd al-Malik had taken him under his protection against Óajjaj, and had requested the Caliph Walid to forgive the fine of 6.000 .000 dirham for Yazid. This request had been accepted by the Caliph. In conclusion, Yazid had been a close friend to Sulaiman in the course of time.12 It was clear that Yazid normally had supported him as heir apparent of Walid b. 'Abd al-Malik.

According to the narrative of al-Madāini mentioned above, although Sulaiman b. 'Abd al-Malik, the new Caliph, had read all of the three letters and been angry about the manner of Qutaiba, he ratified his governorship in Khurāsān. But Qutaiba had had a prejudice that he would have been dismissed by the Caliph Sulaiman, and rebelled against him without waiting for his decision. Qutaiba proclaimed that he didn't recognize Sulaiman as caliph, and demanded the 'Arab tribes support him against Sulaiman. At this time Qutaiba received information about his ratification, but he had an opinion that it was impossibble to avoid the rebellion and to give credit to the Caliph Sulaiman for his loyalty. ${ }^{13}$ Even according to al-Batädhuñ, Qutaiba was anxious about the fact that this ratification was temporal, and that Sulaiman would tried to make him and the 'Arab tribes in Khurāsān to give homage. ${ }^{14}$

Whatever Sulaiman intended for, in any case, it seems that he did not behave sentimentally, but in the responsibility of a statesman about the governorship ratification of Qutaiba. Because the Caliph Sulaiman at least temporarily did not react against the supporting of Qutaiba his being dismissed from heirship apparent. In spite of the threatening letters, he ratified the governership of Qutaiba. It seems that as a new caliph, Sulaiman firstly considered that he must control the whole country as it was. In addition, Qutaiba was the most successfull governor among the ones who had governed until that time in Khurāsān and Transoxiana, and he had been able to control the region. If affirmatively seen and totally evaluated, the letters referred that Qutaiba wanted to govern successfully as before he did.

\footnotetext{
12 al-Ùabañ, VI, 448-453.

13 al-Ùabari, VI, 508-509.

${ }^{14}$ al-Balädhuñ, 616.
} 
Therefore taking successful governing of Qutaiba into consideration, the Caliph Sulaiman could have probably forgiven his mistaken behaviour.

\section{The Death of Qutaiba b. Muslim}

Qutaiba b. Muslim accepted the opinion of 'Abdallāh b. Muslim, his brother, and didn't wait for the decision of the new Caliph, Sulaiman b. 'Abd alMalik, and rebelled against him. But the 'Arab tribes of Khurāsān left Qutaiba alone, whereas Qutaiba had expected them to help him against the new Caliph. Qutaiba was so angry at this behaviour of 'Arab tribes, including Ahl al-'Alliye, Bakr b. Wāel, Tamim, Qais, Azd that he insulted hurtfully them. In this period there were 9000 of Ahl al-'A liye, 10.000 of Tamìm, 4000 of 'Abd al-Qais, 10.000 of Azd, 7000 of Bakr b. Wàel, 7000 of Mawāli as soldiers in Khurāsān. ${ }^{15}$ Therefore Qutaiba's behaviour made him these 'Arab tribes enemies. Even his family was not able to tolerate Qutaiba's behaviour against 'Arab tribes, and said that he left himself alone. Qutaiba said that he was very angry at their insensibility in the appointment of Sulaiman as caliph. But his apology wasn't able to calm 'Arab tribes. ${ }^{16}$

The anger of 'Arab tribes with Qutaiba were connected with the events which had happened in the past. Firstly 'Arabs in Khurāsān had quarrelled with each other until the governorship period of Qutaiba, and acted together generally for their self-interest. ${ }^{17}$ In addition there was some crisis made pause in Qutaiba's powerful period. For example Qutaiba had killed some people of the Ahtamids tribe who was the subgroup of Tamim tribe.18 Therefore Tamim tribe had wanted to revenge for the dead.19 Waki b. Abi Süd, the leader of Tamim tribe, was so angry with Qutaiba that he even had stopped regular prayers saying "How I pray to God who didn't become angry with Qutaiba who killed our sons?"20 Qutaiba had dismissed Wakr

\footnotetext{
15 al-Balādhurī, 617; al-Ùabañ, VI, 512; Ibn A'tham al-Kūfī, IV, 193-197.

16 al-Balādhuñ, 615-616.

${ }^{17}$ See more information: Hasan Kur, "Süfyānī Emeviler Sonrasinda Horasan ve Maveraünnehir'de İç Mücadeleler (64-85/683-704)", Ankara Üniversitesi Ilahiyat Fakültesi Dergisi, XIII, 273-304.

$18 \mathrm{Ibn}$ Óazm al-Andalusī, Camharatu Ansäb al-'Arab, (Beirut 1983), 217.

${ }^{19}$ Ibn A'tham al-Küfī, IV, 197.

$20 \mathrm{al}$-Balāahuri gives us a detailed account of some members of Ahtamids' being killed. According to him, Qutaiba had appointed 'Abdalläh b. al-Ahtam as his depury in Marw. But 'Abdallāh b. al-Ahtam had been tried to discredit him in the eye of Oajjaj, Viceroy of 'Iräq and Khurāsān. For the first time Qutaiba hadn't considered some information given him important, and he had blamed informers to be jealous of the deputation of "Abdallah $b$. al-Ahtam. There had been also Bashir, one from the nearest relatives of 'Abdallah $b$. al-Ahtam, among the informers. However Qutaiba had obtained the letters 'Abdallāh al-Ahtam had written to Hajjaj, and had wanted to severely punish 'Abdalläh b. alAhtam but hadn't caught him. Therefore Qutaiba had executed nine persons from the sons of
} 
from the leadership of Tamim tribe since he had led his relatives to revenge, and had appointed ëırār b. Óuãain al-ëabb $\bar{i}^{21}$ instead of him.

Qutaiba had also punished Iyās b. 'Abdallāh, the governor of Khwārazm, and Óaiyān al-Nabaùi, the commander of Mawālid22, or client, soldiers since they had been unsuccesful in their duties. Therefore Haiyān had been longing for revenge on him.23

The sons of Soghdian kings supported Qutaiba besides his family and relatives. These Soghdians continued his supports although they were tried to be separated by Óaiyān al-Nabaùi and many other persons. ${ }^{24}$ Qutaiba was aware of the reliability of Soghdians. Therefore because of his fear of Sulaiman b. 'Abd al-Malik, while he had campaigned to seize Kashgar in 96/715 just before the Caliph Walid had died, he had led his family to Samarqand and made them dwell there; and he had settled an army unit under a Marealid commander called as al-Khwārazmī in the passageway of Oxus, according to Ibn A'tham al-Küfī in Nishāpür, so that he had controlled the passage to Transoxiana. Ibn A'tham narrated that alKhwārazmi had informed Qutaiba the appointment of Yazid b. al-Muhallab as governor of 'Irāq. ${ }^{25}$ Qutaiba had threatened 'Arab tribes in Khurāsān that if they didn't side with him, he would want Mawālìd soldiers to help him against them. ${ }^{26}$

Thus it appeared that the decision of Óajjāj to enlist Maneali was appropriate. But Maweali were considered as second class soldiers in comparison with 'Arabs, and weren't able to get a share of booties at wars since they were not registered in dineam, or roll of the 'Arab warriors. For this reason Mareali and 'Arabs could not unite to form one-community. If it could be formed, the whole Mareali would have probably supported Qutaiba, and 'Arabs wouldn't have revolted against him, or the revolt couldn't have been suppressed before long. ${ }^{27}$ But because of Óajjäj's profit gaining aim in short period, Marealid policy wasn't able to be developed. Therefore the

\footnotetext{
'Abdalläh b. al-Ahtam and his uncle since they probably hadn't handed over him to Qutaiba. Even there had been Bashir among the executed ones. Qutaiba had charged him with behaving hypocritically and hadn't accepted his apology. (See al-Balādhuñ, 617, 619-621; al-Ùabañ̄, VI, 512.)

${ }^{21}$ al-Balādhuri narrated this name as "one from the sons of ërrar al-ëabbi". See al-Balädhuñ, 621.

22 The term of mawali (pl. of maula) appears many times in the sources as one who joined Islam in the early days of the conquests.

23 al-Üabañ, VI, 480; Shaban, 65.

24 al-Balādhurī, 618.

${ }^{25}$ al-Ùabari, VI, 500; Ibn A'tham al-Kūfí, IV, 189.

26 al-Balädhuri, 616.

27 Shaban, 73.
} 
Islamization process of Transoxiana wasn't able to be completed, and also the life of Qutaiba and the government stability couldn't be kept safe.

Consequently 'Arab soldiers more than 50.000 became enemies of Qutaiba. His rivals had a chance that they couldn't have before. 'Arabs severely reacted against both that he was in rebellion against the new caliph Sulaiman b. 'Abd al-Malik, and that he insulted them. They agreed on overturning from his governorship. But there was a possibility that a struggle could happen among the 'Arab tribes. However it's powerless, the tribe of Qutaiba, Bähila, was the subgroup of Muêarr tribe which was much powerful in Khurāsān. Therefore although being much angry with Qutaiba, Muêāiids could support him while other 'Arab tribes were trying to overturn him. So as to prevent that support, they elected Wakr b. Abi Süd as leader for the movement, who was from Tamìm of Muêār. ${ }^{28}$

Wakri was very happy to be elected as leader, and accepted it. But he was a sincere friend of "Abdallāh b. Muslim, the brother of Qutaiba. They were entertaining themselves and drinking together most of the time. Even 'Abdallāh couldn't belive that Wakr was the leader of 'Arab rebels. ${ }^{29} \mathrm{Wakr}$ tried secretly to unite people under him. Qutaiba was informed about the intrigue of Waks'. Qutaiba called him, but Waks didn't want to meet him. So Qutaiba attempted to forcely bring him but he couldn't. Because Wakt and his large following attacked to kill Qutaiba. There were only Bāhila tribe and, according to Ibn A'tham, Qais-'Ailān tribe under Qutaiba. As a consequence of the bloody clash between them, Qutaiba and many of his relatives were killed. According to Abū 'Ubaida, Waks' hanged the bodies of men killed to the number of 11.30

The rebellion of 'Arab tribes surprised the natives of Khurāsān. One of them said to "Arabs: "If Qutaiba had been our leader and died among us, we wouldn't have behaved as you did. On the contrary we would have put him into a coffin, and when campaigned we would have requested him to help us for victory. Nobody else could be successful as governor in Khurāsān. However, you showed him ingratitude." The Ispāhbad of Ùabaristān compared Qutaiba with Yazìd b. al-Muhallab, who had governed Khurāsān in $97 / 716$, and said that the rebellion of 'Arabs surprised him and that

\footnotetext{
28 al-Balādhurī, 615-617; al-Ùabari, VI, 509-510; Ibn A'tham al-Küfî, IV, 197-198.

${ }^{29}$ al-Ùabari, VI, 512-513.

30 al-Balādhuri, 618-619; al-Ùabarī, VI, 510-516; Ibn A'tham al-Kūfīi, IV, 199-201.
} 
Qutaiba seemed to the natives so magnificent that fettered Qutaiba in a distant dungeon would have more influence than Governor Yazid. ${ }^{31}$

\section{Governorship Struggle after Qutaiba b. Muslim}

'Arab tribes weren't reconciled by ending of the clash, and insecurity in Khurāsān and Transoxiana continued. It was an important problem who the new governer would be, and there were many candidates for this. For example after the clash came to an end, Wakis b. Abi Süd sought the cut head of Qutaiba and his seal, but wasn't able to find them. They were very important to prove that he killed Qutaiba, since they would facilitate his appointment as governer. Thus Bukair b. Wishāh, the governor of Khurāsān of Umaiyad Caliph 'Abd al-Malik b. Marwān, had claimed that he had killed 'Abdallāh b. Khāzim al-Sulamī, the governor of Khurāsān of Abdallāh b. Zubair, for holding his governership in 72/691, and sent 'Abd al-Malik his cut head.32 Therefore Waki threatened with a clashing if the cut head of Qutaiba and his seal was handed over him. Accordingly in consequence of seeking it appeared that they were obtained by 'Abdallāh b. Óavzān, the leader of Azd tribe; and they were handed over Wakr. It seems that the leader of Azd tribe also tried to govern. Wakis sent the Caliph the head of Qutaiba by a delegation, including 'Arab tribals except for Tamim tribals, his relatives. ${ }^{33}$ This refers that Wakit holded moderate political opinions, although he had a strong desire to hold governership. Thus he both wanted to give the Caliph Sulaiman impression of the fact that all tribes agreed on his appointment as governer and honoured them. In addition, he kept his promise which he made Óaiyān al-Nabaùi, the leader of Mawāti, during which it was planned to clash against Qutaiba, ${ }^{34}$ and appointed him to control over the river of Balkh (Oxus) surroundings and to collect its tax.35 He forbade plundering of Bāhila, the Qutaiba's tribe, and ordered the rebels to give things plundered before forbiding back. According to Ibn A'tham, he executed a man for plundering by cutting his head. ${ }^{36}$

After the death of Qutaiba, it was uncertain which policy was needed by new Umaiyad Caliphate. Because the event had been out of control of

\footnotetext{
31 al-Ùabari, VI, 519.

32 al-Ùabarī, VI, 177; Ibn al-Athīr, al-Kāmil fì al-Tārikh, (Beirut 1965), IV, 346; Ibn Kathìr, VIII, 350; Ibn Khaldūn, al-'Ibar wa Dīwān al-Mubtada' wa al-Khabar, (Beirut 1979), III, 36-37.

33 al-Balädhurī, 618; al-Tabarī, VI, 518, 526; Ibn A'tham al-Küfí, IV, 204.

34 al-Ùabari, VI, 518.

${ }^{35}$ al-Ùabari, VI, 512.

36 Ibn A'tham al-Küfi, IV, 205.
} 
Caliphate. However, even temporarily there wasn't any problem since the rebels recognized Sulaiman as caliph. Therefore the new Caliph didn't intervened Waks̄ to control over Khurāsān and Transoxiana. Accordingly Wakī behaved as if a legal governor. He appointed Abū Micladh Läóiq b. Óumaid in Marw by the agreement of rebels, and declared that Qutaiba had increased prices but he himself would reduce them and a pair of scales would be four dirhems from next day on and he would execute the men who would increase price and he would never abandon this decision. ${ }^{37}$ As mentioned by Shaban, the high inflation was a natural situation in the period of Qutaiba. Because a considerable amount of booty was obtained in wars and the countryside was also deprived of its needed manpower, which created a war economy, to use a modem term, and changed the balance between the supply and demand. 38

Peace and security began to appear in Khurāsān nine months after the death of Qutaiba, and so the situation of Waks was reviewed by the Caliph and his rulers. Because the Caliph Sulaiman had disliked the being killed of Qutaiba out of his order. Accordingly he had spoken to the delegations, who had brought the cut head of Qutaiba, with great dislike.39 Thus later, the Caliph Sulaiman ordered the governer of Khurāsān, whom he appointed, to arrest Wakis', if Qutaiba had not rebelled against him. ${ }^{40}$ On the other hand the agreement of rebels about the leadership of Wakr was only with the clash against Qutaiba, but not with his govemorship. They saw him as a tribal leader. ${ }^{41}$ As mentioned above, at first disappearance of Qutaiba's cut head and his seal also confirms this reality.

At the beginning the Caliph Sulaiman thought to appoint 'Abd al-Malik b. al-Muhallab as the governor of Khurāsann. But Yazìd b. al-Muhallab attempted to be appointed the governorship of Khurāsān via 'Abdallāh b. alAhtam, and, according to Abū 'Ubaida Ma'mar b. Muthannā, gave him 100.000 dirhams. ${ }^{42}$ "Abdallah $\mathrm{b}$. al-Ahtam claimed during the interview with the Caliph Sulaiman that Wakt was very rough and naturally a bedouin. ${ }^{43}$ Whereas Waks', as mentioned above, had protected the tribe of 'Abdalläh $b$. al-Ahtam not to suffer at his hands against Qutaiba, and accordingly had

\footnotetext{
${ }^{37}$ al-Ùabari, VI, 512.

38 Shaban, 71.

39 al-Ǔ̉abari, VI, 519.

40 al-Ùabani, VI, 527.

41 al-Ùabañ, VI, 511.

42 al-Ùabari, VI, 524-525.

43 al-Balädhuri, 619.
} 
been dismissed from the leadership of Tamim. However, it seems that 'Abdallāh b. al-Ahtam was hardly grateful and faithful to him. In conclusion, the Caliph Sulaiman appointed Yazid b. al-Muhallab the governership of Khurāsān, as well as 'Irāq's.44

At first Yazìd deputized Khurāsān his son Mukhallad. So Mukhallad come to there in $97 / 716$, and went over the income and expenditure accounts of Wakis, and accordingly blamed him and his officers to embezzle, and arrested them. Thus both Qutaiba, who rebelled against the new Caliph Sulaiman, and Wakit, the leader of rebels against Qutaiba, declined from power. The Caliph Sulaiman appointed a governer, who entirely belonged to him.

\section{Conclusion}

Some events occured during the Qutaiba b. Muslim's struggle for staying in power helped us draw some conclusions about this period. In this context, after his death, the political order which Hajjajj, who had died one year earlier than Qutaiba's death, had established through Qutaiba came to an end. Qutaiba's death not only pointed out that it was very difficult for a governer who had lost the popular support in the period in question to keep his position after the power, which he rested on, came to an end, but also showed that his successful works and the possibilities provided for the people were not sufficient to gain popular support. In addition, it put forward that he should have regarded their sentiments. Indeed, when Qutaiba insulted the 'Arabs since they did not support him in his revolt against the new caliph Sulaiman, it led them to disregard the successes and the solidarity provided by him in the past. Despite all efforts of Wakŝ, the leader of revolt against Qutaiba, he failed to be appointed to the governorship of Khurāsān. This showed that the central administration had not a positive view on a leader who seized the power out of its control, even he proclaimed his obedience to it. Because for the Caliph it was more suitable to appoint a person who entirely owed his power to him as a governor than to appoint such a person, namely $W a k^{-1} b$. Abi Süd. For one who took power through a coup may be, more or less, convinced that he seized the power with his own hand. And this may weaken the authority of caliph in the region in question. Indeed, the Caliph, soon after the death of Qutaiba, reappointed Yazid b. al-Muhallab there, whom Hajjāj had dismissed from the governorship of Khurāsān. In conclusion, a new power period appeared in Khurāsān and Transoxiana.

44 al-Ùabarī, VI, 523-526, 528; Ibn A'tham al-Küfī, IV, 197-207. 